Pakistan Journal of Humanities and Social Sciences

July - December 2017, Volume 5, No. 2, Pages 79 - 103

\title{
The Factors Affecting Employee's Performance of Higher Education
}

\author{
Sameera Iqbal ${ }^{1}$; Nazim Baluch ${ }^{2}$; Che Sobry Abdullah ${ }^{3}$ \\ ${ }^{1} \mathrm{Ph} . \mathrm{D}$. Scholar, School of Technology Management and Logistics, College of Business \\ Universiti Utara Malaysia \\ Email: sameeraiqbal786@hotmail.com \\ ${ }^{2}$ Senior Lecturer, School of Technology Management and Logistics, College of Business \\ Universiti Utara Malaysia \\ ${ }^{3}$ Professor, School of Technology Management and Logistics, College of Business
}

\begin{abstract}
The role of higher education in the progress of a society is indispensable. It shapes up the minds, mold behaviors and develops distinctive capabilities in the human being to serve the society better. Higher Education in the Arab World began to emerge and spread after the mid-twentieth century. There is a dearth of empirical research pertinent to the employee performance in general and employee performance in higher education. This condition had therefore illuminated a significant gap in the education sector of KSA that tends to focus on overall sectoral problems and organizational level problems in respect to job performance. Thus, the present study may contribute to the existing literature on Public Sector Universities in KSA through proposed a research model which has not received much attention.
\end{abstract}

Keywords: Role Ambiguity; Job Satisfaction; Training; Leadership; Employee Performance

\section{Background of the Study}

The increasing financial resources at the disposal of the country since the start of oil exploitation in 1938 had a tremendous impact on the development of the educational system. As the Kingdom entered in a period of significant economic development, the Government recognized the need for educational institutions that would equip Saudi citizens for the emerging domestic labor market. At that time, the country lacked enough skilled workers to manage the new economy (Jamjoom, 2012). Over the years, the education system enjoyed a steady, though slow development until a wave of rapid development in the 1970s. The advent of an increasingly integrated information and knowledge-driven global economy are other recent factors leading the Government to give this sector highest priority for further development.

At the time of the founding monarch, King Abdul-Aziz, the country had no higher education institutions. The highest educational level a student could achieve was to graduate 
from the Preparatory Scholarship School, which was established in 1935 under the supervision of the Directorate of Education. This establishment only prepared students for university education in other countries (Royan et al., 2007). The first Saudi group of students to pursue higher education was sent in 1926 on scholarship to Al-Azhar University in Egypt. However, the government soon realized the necessity of having its own higher education system and thus began to build and expand it.

According to the Mohe (2010) report, the development of the Saudi higher education system went through three stages. During the foundation stage (1949-1960), the building blocks of the higher education sector were developed. The first college was opened in the Kingdom in 1949. That was the Faculty of Sharia (Jurisprudence) in Makkah (Al Gahtani, 2002). Less than five years later, two colleges were established in Riyadh, the College of Jurisprudence and the College of Arabic Language. The educational orientation and emphasis on religious subjects and language remained at the core of the curriculum. In 1957, a royal decree approved the establishment of new public universities. In sheer numbers, it appears that there are twelve new public universities since the last one was established in 1998.

During the expansion stage (1961-1980), new higher education institutions were established, including universities, teacher training colleges, and women colleges. Six new universities were established in the major cities of Medina, Jeddah, Makkah, Riyadh, Dhahran, and Al-Hasa. Branches of these universities were established in a limited number of cities, like Abha, Qaseem, and Ehsa (Mohe, 2010). Among the existing eight universities, two were Islamic universities with no colleges for science and technology and the third, King Fahad University of Petroleum and Minerals, has no colleges for religion, humanities or social sciences (Agut \& Grau, 2002). Teacher training colleges and women's colleges are higher education institutions that specialize in producing teachers for general education; the former is for male students while the latter is for female students who later teach in girls' schools. Degrees in education were offered to students upon the completion of a four-year program, which include the practical teaching requirement. Female enrollment in these colleges has been relatively high, perhaps because teaching was the only profession available to women besides working in the health sector.

The third phase of development was the comprehensive stage (1981-2009). After the establishment of Umm Al-Qura University in Makkah in 1980, no new universities were established until the year 1998, with the establishment of King Khalid University in the southern region. This was not the birth of a new institution, but the result of merging two 
local branches of two main universities, the south branches of Imam Mohammed bin Saud Islamic University and King Saud University. Between 1998 and 1999, new forms of higher education were permitted--private higher education institutions and community colleges, which were detailed later in this chapter. However, it was not until 2009 that a royal decree approved the establishment of new public universities. In sheer numbers, it appears that there are twelve new public universities since the last one was established in 1998 (see table 1.2). In fact, however, there are only five new schools; the other seven are the result of merging branches of existing universities. This situation underlines the fact that there has been little expansion in the sector for almost two decades, especially at the university level.

Thus, "excellent job performance has to be maintained and labor class workforce should be well equipped with the skills which are actually needed, to guarantee that the business was not in misfortunes because of the absence of obliged attitudes at both levels, broadly and globally (Tomaka, 2001) and academia (Higher education sector) is not an exemption in this context. In addition, employees in a service setting also need to possess the right competency in order to be effective in their job performance. It is necessary for service workers to be skilled and trained in order to deliver effective service and enhance their job performance. Some examples of competencies that are necessary for service employees consist of friendliness, concern, insight, communicative and adaptive were noted. Past studies (June, \& Mahmood, 2011; Vakola, Soderquist \& Prastacos, 2007; Potluri \& Zeleke, 2009) examined the relationship of competency and job performance were led abroad and then reevaluated in KSA to align these studies' outcomes in the context of KSA (Ahmad, Ramayah, Wilson \& Kummerow, 2010; Azmi, 2010). Moreover, higher education in Saudi Arabia has experienced an enormous development throughout the most recent five decades. The advanced education framework, which is focused on enhancement, has extended to incorporate the several colleges into 26 government universities; moreover, there are 47 private universities and colleges.

According to the academic ranking of world Universities, most of the Universities of KSA are not even fall in any international category of world ranking universities. Out of its five public Universities, only three universities (King Saud University, King Fahd University, and King Abdul Aziz University) fall somewhere in the list of academic ranking of world universities. Remaining two (King Khalid University and University of Tabuk) are not even the part of the list as they do not fulfill the criteria to be in the list on the basis of academic performance. Three universities which are listed in the ranking are not showing the 
improvement in ranking not even in the form of consistency (Darandari \& Hoke, 2013). Academic ranking purely refers to the performance of academic staff. So, it can be observed that the employees of these universities are not showing their best performance and that is the reason that these universities failed to place themselves in a good position in the list of World academic ranking.

Moreover, low performance of staff is due to the dissatisfaction with job. The existence of employee dissatisfaction is characterized by a lack of treatment commensurate with the achievements that have been achieved, loyalty, dedication and honesty. So, in order to improve employee performance-job satisfaction is essential to let them perform well. The problem above caused it hard to ignore, even on the contrary that the performance and employee satisfaction plays an extremely important and decisive for the success and failure of an organization. Thus, the need to study on role ambiguity as a variable emerges on the grounds that in any administration setting, an employee who has the capacity comprehend and clear about their roles in the organization are prone to perform well in their employment (Anderson, 2006). In the meantime, the past scrutinizes identified with representatives that work in an administration setting (Murkherjee \& Maholtra, 2006; Lang, Thomas, Bliese, \& Adler, 2007) had demonstrated that role uncertainty impacted the workers' employment performance. This condition had therefore illuminated a significant gap in the education sector of KSA that tends to focus on overall sectoral problems and organizational level problems in respect to job performance. Thus, this research aims to propose the factors affecting employees' performance through job satisfaction, training and leadership in the higher education in KSA.

\section{Literature Review}

\section{A. Employee Performance}

Jamshidi, (N.D.) states that performance refers to the distinctiveness of a person's achievement in his task. Then, the performance generally involves the certain level of an individual's output for example number of customers dealt or a number of units sold and the comparison of the performance with the set benchmarks of the organization (Al Kazemi \& Ali, 2002). Winarno (2008), define performance as "something that is done or the products or services produced or provided by a person or group of people". Usually, people conceive job performance as the work done by the employee during his job at his workplace. Nature of job, overall environment and difficulty level can affect the job performance of an employee (Ackerman, 1997, Avery and Murphy, 1989). This also noted that most of the definitions of 
job performance are not comprehensive and not able to give the full meaning of this term (Campbell et al., 1996).

Moreover, the empirical study revealed there was a positive relationship between organizational commitment and job performance and this finding indicated a stronger relationship occurred among the sales employees than non-sales employees. Job satisfaction had also received attention from other researchers. In the same way, through a study that was conducted on the casino employees in Macau, it was also discovered that job satisfaction was significantly related to job performance and had a positive effect while at the same time lack of interpersonal skills had also found to contribute to poor performance ( $\mathrm{Gu} \& \mathrm{Chi}, 2009$ ). Meanwhile, the research was also conducted to determine whether job demands and job resources could affect the job performance while being mediated by burnout among the front employees working in the banking sector (Babakus, Yavas \& Ashill, 2009). The study also examined the moderating role of customer orientation in the relationship. The results indicated burnout intervenes the job performance has an impact on job demands and job resources. Client introduction was connected specifically to burnout and occupation execution and go about as a cradle to the broken impacts of job demands on burnout and job performance.

Another study found that there are three types of performance. One of them can be classified as output rates, the number of units sold over a stipulated time of period, the number of units produced by a group of workers etc. the second type of measure can be categorized as the measure of performance of an individual to rate them by any other individual. Self-rating and self-appraising are known as the third measure of performance. So, by incorporating self-appraisal and self-rating tools employees can be encouraged to enhance their capabilities and to make their performance better than the previous. Employees can also understand their designated role in the organization by opting self-measure techniques. Therefore, job performance is used to measure the organizational achievements and personal capabilities and to enhance an individual's work efficiency and to judge any other person's output (Hersey \&Blanchard, 1993; Chen, Yang, Shiau \& Wang, 2006).

\section{B. Job Satisfaction}

Job satisfaction is a very crucial element for a corporation, numerous managers or bosses would not dither to know whether their representatives or subordinates are fulfilled by their employment. Work fulfillment is characterized as a mentality that people have about their occupations. It is a degree to which one feels absolutely or contrarily about the inborn 
and/or outward parts of one's employment (Bhuian and Menguc, 2005). It is observed that job satisfaction is a very crucial element for a corporation. Numerous managers or bosses would not dither to know whether their representatives or subordinates are fulfilled by their employment. Work fulfillment is characterized as a mentality that people have about their occupations. It is a degree to which one feels absolutely or contrarily about the inborn and/or outward parts of one's employment (Bhuian and Menguc, 2005; Hunt et al., 1985).

According to Sharma and Jyoti (2010), three factors affect an academician's job satisfaction. Those factors were intrinsic factors, extrinsic factors, and demographic factors. In their study, they used the term teachers instead of academicians. Since the terms teachers and academicians referred to the same job sector that interaction between teachers and students exist, this study accepts that teachers and academicians can be used interchangeably. The best example of intrinsic factors affecting an academician's job satisfaction is the features of students and the perception of teachers about how they control the class (Lee, Dedrick \& Smith, 1991). Conferring professional autonomy enhances the attraction of the teaching profession as the best choice for the career and enhances the overall effectiveness and efficiency of teaching and practices (Boe \& Gilford, 1992). Apart from that, having conferred professional autonomy was indirectly motivate individuals to join the profession of teaching as they can enjoy their profession (Boe \& Gilford, 1992) because of salaries, prestige, and other benefits many academicians join the field of education (Choy, Bobbit, Henke, Horn, \& Lieberman, 1993). Extrinsic factors or "hygiene" influence job dissatisfaction (Iiacqua \& Schumacher, 2001; Tietjene \& Myers, 1998). It relates to work environments (Sharma \& Jyothi, 2010) including salary, benefits, institutional environments (Lootens, 2009). When there is a lack of support in their work, they felt unmotivated to do their best for the students. Hence, when they are not satisfied with their working condition, they are more likely to opt out of their present situation or work environment (Choy et al, 1993). Job satisfaction in academicians has been related to demographic variables including age, education, marital status and gender (Corbin, 2001; Feldman \& Turnley, 2001; Laden \& Hagedorn, 2000; Looten, 2009; Sharma \& Jyoti, 2010). Perie and Baker, (1997) reported that female teachers have a higher level of job satisfaction but found weak correlations with salary and benefits.

Most literature concerning research in academicians' job satisfaction adapted Herzberg's motivation-hygiene theory. Herzberg's motivator-hygiene theory is one of the earliest theories of job satisfaction. The theory proposed that every employee has two sets of needs or requirements, that is, motivator needs that are associated with the actual work itself 
and the challenges it carries; and hygiene needs that are associated with the physical and the psychological environment in which the work is performed. Some job facets that represent motivator needs are the responsibility and the amount of authority that the job carries. Hygiene needs can be represented by facets such as working environment like air conditioning, security of the job and amount of pay. A unique characteristic of this theory is that an employee can experience satisfaction and dissatisfaction of his job at the same time.

\section{Leadership}

In line with the definitions, organizational theories of leadership are used to theorize how organizations function and how they affect and are affected by the environment in which they operate. For example, trait theories of leadership focused on personal qualities and characteristics to differentiate leaders and non-leaders. A comprehensive review of personality traits is represented by the Big Five personality (McShane \& Glinow, 2010; Robbins, Stephen and Coulter, (2003). From the Big Five personality, the personality dimensions are conscientiousness, agreeableness, neuroticism, openness to experience, and extraversion. These five personality traits were largely studied and used by many researchers due to their elements are important to explain on workplace behaviors and performance outcomes. It is a style of leadership which relied on an exchange process between leaders and followers. Value-based pioneers concentrate on the elucidation of assignment prerequisites and the particular of unforeseen prizes (Bass, 1999).

Stashevsky and Koslowsky (2006) cited Meglino, Ravlin and DeNisi (2001) in their study that a leadership is important in enhancing the performance of organizations. Thus, focusing on 252 ex-MBA graduate students, the study used three sources of data to examine the antecedents of team performance. The three sources of data were a written questionnaire, exam results from each respondent, and team performance score composed of the team assignments grades, and on the performance firm rating. Their study dimensions consisted of leadership style, gender, knowledge level, team cohesiveness, and team performance. Numerous associations feel that their kin can give leverage, and in this manner, their kin helps the association's performance. Representatives assume a crucial part of authoritative achievement (Collis \& Montgomery, 1995). Employee performance has been demonstrated to have a critical positive impact on authoritative execution (Collis \& Montgomery, 1995). One of the significant pitfalls in an association happens when chiefs accept their associations are always working at the largest amount of effectiveness, or that they don't oblige data from their employees (Foot \& Hook, 2008). 
It can be seen that the singular's performance has an effect on the association's more extensive destinations, and it is in this manner basic that each employee's performance ought to be overseen. This methodology of performance administration incorporates bunch appraisals and companion audits and composed reports (Hellriegel, et al., 2004). Lately, performance administration frameworks have ended up more critical in light of the fact that chiefs are under consistent weight to enhance the performance of their associations (Holloway, Francis, and Hinton, 1999). As the performance of association's impact, the associations proceeded with presence, it is along these lines important to examine the idea of dealing with this performance. The main goal of all types of manager is to enhance the organizational efficiency by increasing production level and overall performance. Job satisfaction always brings in the high motivation level (Boyett, 2000). Managers need to take it as a challenge to provide a healthy working environment to make employees at ease level and perform more.

\section{Training}

The previous researchers explored generous thoughtfulness regarding the foundational works. Andres Ericsson, and to the following research that based upon his hypothetical skeleton of conscious practice. Audit of the foundational research in the field of corporate preparing guaranteed a substantive examination of the applications of intentional work on preparing in business situations. The writing survey incorporates ponders the effect of preparing on organization gainfulness, the maintenance of staff, and staff performance, for example, those directed by Jones, Latreille, and Sloane (2009). Late investigations of purposeful work on preparing for scholarly and proficient connections are in the audit, and other doctoral works identifying with this subject and utilizing comparable methodological techniques. Studies about the creative utilization of engineering in instructional outline and in the conveyance of fitting, convenient input, both of which are foundational parts of the intentional practice system, is in this part. An examination of the significant present and foundational writing identifying with grown-up learning hypothesis is likewise included.

A standout amongst the most provocative regions of Ericsson's examination incorporates a test to the aphorism that elevated amounts of experience connect with elevated amounts of skill (Ericsson, 2008). Since one of the objectives of the study was to measure the effect of planned work on preparing on representatives of differing knowledge levels, Ericsson's hypothesis that practice is a more critical component than involvement in deciding ability gets noteworthy consideration in the survey. The extra research comes from that 
endeavor to evaluate whether specialists have adopted more through experience than through broad practice are underlined. Opposing research on the securing of predominant abilities and the impediments of conscious practice in clarifying abnormal amounts of ability are ideas analyzed in the pertinent writing. Feedback of planned practice exploration incorporates the individuals who have scrutinized the examination approach, the potential for specialists to minimize elements, for example, inherent ability and sagacity, and the absence of predictable evaluation of the sum and nature of the practice needed to evoke behavioral changes is predominant in the related writing.

In the quick pace changing universe of business and ecological vulnerability, corporations understand its impediment to managing new difficulties (Tai, 2006). Nonetheless, it further expresses that the organizations ought to put resources into preparing projects to make their workers sufficiently equipped to face instabilities and take viable choice in time, so as to stay focused in the business. Compelling preparing is advantageous for the firm in a mixture of courses, for example, it assumes an imperative part in building and keeping up capacities, both on the individual and hierarchical level, and accordingly partakes currently authoritative change (Valleet, 2000). Besides, it improves the maintenance limit of the capable workforce, subsequently diminishing the unintentional occupation turn of the specialists (Jones and Wright, 1992; Shaw, 1998). Moreover, it demonstrates the association's long-haul duty towards its specialists and builds the representative's motivational (Pfeffer, 1994). All these commitments lead further bolstering an attaining good fortune and to an improvement in representative execution and authoritative benefit (Delery, 1996).

Training programs are considered the effective tool to enhance the employee performance. "The training focuses on the gap between current to bridging results and performance of the desired standard". There are different methods of giving training such as mentoring and coaching, go to collaborate and share the subordinates. The teamwork in training session's employees to participate actively in the workplace and to provide enhanced performance to enhance the overall performance of the organization.

\section{E. Role Ambiguity}

Several dimensions were measured and found to be significantly related to the ambiguity an individual felt in his or her role. These include emotional sensitivity, introversion-extroversion, flexibility-rigidity, and needs for career achievement. The study found that those with higher sensitivity to emotion experienced higher tension scores in the context where their jobs are ambiguous. Likewise, introverts were found to be more 
susceptible to tension and stress when their role was uncertain. Finally, an individual who has higher career aspirations has a generally higher level of engagement in his or her position and any stress or confusion with that position role is more pronounced than for those with less engagement with their positional roles. For interpersonal factors, the sources of pressure and role expectations were measured. For example, the greatest pressure on an employee likely came from other employees working directly with the employee. Sources of influence can include direct organizational superiors, employees within the same organizational unit, and employees or peers outside an employee's organizational unit. The study shows that typical reactions to pressure or communication from most of these sources, but especially, direct organizational superiors and employees within the same organizational unit, is withdrawal or weakening of communication channels with these individuals.

Measurement of these three dimensions of role ambiguity (organizational factors, personality factors, and interpersonal factors) in addition to the construct of role ambiguity, itself, has shown to better provide a full picture of the nature of role ambiguity. In terms of measurement, the multidimensional aspect of role ambiguity identified by Beauchamp, Bray, Eys and Carron (2001), and described above has been further supported by studies in the occupation of sports teams. It has been shown that role ambiguity, measured through dimensions, has successfully been measured as a multidimensional construct when studied with satisfaction (Beauchamp et al, 2005), role conflict, leadership role (Beauchamp, et al.,2005) and athletes' perceptions of the sources of role ambiguity (Beauchamp et al., 2005).

Moreover, Beauchamp et al., (2005) examined whether an individual's perception of a lack of clear and consistent information about his or her role is a significant factor in performance in individual and group work settings. In a qualitative study of the subject, using a sample of 151 athletes from several interactive sports, the researchers asked the respondents a series of open-ended questions regarding role ambiguity. An inductive approach was used in analyzing the data, whereby researchers first sorted the data based on keywords into groups, then four researchers independently created labels and grouped like units into similar groupings. The consensus among the four researchers was high for the groupings: scope of responsibilities $(92.5 \%)$, behavior to fulfill responsibilities $(93.7 \%)$, evaluation of role performance (94.3\%), and consequences of non-performance (90.6\%). Discussion among researchers occurred until $100 \%$ consensus was reached.

Results primarily showed that role sender factors were the major source of role ambiguity, indicating that most players held the role sender, typically a coach or team leader, 
responsible for their lack of clear information regarding their role. This finding supports earlier empirical findings by Mathis and Jackson, (2000) which identified a statistically significant negative correlation between coaching and feedback and role ambiguity, indicating that the fewer input individuals have a leader regarding their performance in a role, the great their perceptions of role ambiguity were toward that role. Role ambiguity has constantly been the focus of studies in the field of human performance. Logically employee can only experience one or the other end of the continuum as when work is performed from the opposite end of the ambiguity of the role is unclear. Mathis and Jackson, (2000) emphasized the importance of having an understanding of their role, from an individual point of view, as it is said to have an effect on your own motivation, satisfaction, and performance.

Furthermore, there were various types of effects resulted from one experiencing role ambiguity ranging from increased psychological stress (Lang, Thomas, Bliese \& Adler, 2007), effects on interests, innovation, self-actualization, autonomy, self-esteem, tensions, physical stress and intention to leave (Beard, 1999) to level of satisfaction (Busch \& Bush, 1978). Given such impacts, role ambiguity can have a serious long-term effect on the success of the job performance of employees. Ilgen and Hollenback (1991) characterized parts as the example of practices that are normal or needed by the parts of an association and related part equivocalness to the absence of certainty that an employee sees of his or her responsibility. Part uncertainty is likewise frequently seen as having an absence of part clarity (Shepard \& Fine, 1994). In an alternate viewpoint, part equivocalness is said to happen as when inadequate measure of data is given to a single person to perform a part and usually seen as a condition when contradiction happens in the work of group with small seeing on the representative side of what is normal for (Mathis, \& Jackson, 2000). Meanwhile, Babin and Boles (1996) viewed role ambiguity as a condition when employees having either lacking in information pertaining to appropriate actions to be taken in a given situation or not having a clear knowledge of the management expectations.

Moreover, the role of ambiguity is also defined as the occurrence of insufficient information regarding the powers and duties, authority to carry out its function (Kahn et al., 1964). This infamous seminal work of Kahn et al. (1964) has set forth the meaning of role ambiguity. The definition given by Kahn et al. (1964) was originated from the formation of a theoretical framework that described two major types of role ambiguity. The first type of role ambiguity known as the task ambiguity happens when employee having a lack of information pertaining to the job, its goals and on how the job can be accomplished. As for the second 
type, known as the socio-emotional ambiguity which Kahn et al. (1964) described as the condition where employee having the concern of what others thinks of them and how their actions can have consequences on their goal attainment. In the same study, Kahn et al. (1964) also discussed further three forms of task ambiguity, which comprised of the scope of responsibility, means-end knowledge, and priority of expectation. The scope of responsibility was mainly a form of ambiguity that relates to the employee having a lack of clarity in terms of the rights, duties and responsibilities expectations. As for the means-end knowledge, it was referred to as having uncertainty in relation to activities that are required to fulfill one's responsibilities and how these responsibilities can be best carried out. Meanwhile, concern on the priority of expectation was looking at how employees may have apprehension on whose and which expectations to be given a priority in carrying out day-to-day work.

Similarly Singh, Verbeke, and Rhoads (1996) generated four dimensions of role ambiguity which comprised of process ambiguity (a person should get things done and how to achieve the organization's objectives), priority ambiguity (when things should be done), expectation ambiguity (what is expected and what employee should be doing) and behavior ambiguity (how employee is expected to act in various situations). Maybe one of the meanings of role ambiguity after the work of Kahn et al. (1964) was given by Rizzo et al. (1970). They said that part uncertainty happened when one is not furnished with great seeing about job responsibility and having little learning of what is relied upon in connection with occupation performance. Then again, part clarity happens when a worker is clear about behavioral desires that aid in giving the fundamental information of what is considered as adequate conduct (Rizzo et al., 1970). Since the opposite end of role, ambiguity is role clarity, one can only experience one or the other as when work is performed (Rizzo et al., 1970). Similarly, Kahn et al. (1964) defined role clarity as the belief of an individual on the expectations and behaviors that are associated with the work-related role.

\section{F. Past Research on Role Ambiguity}

In the past, role ambiguity as a variable had received many attentions and secured a prominent position in many empirical researchers (Tubre \& Collins, 2000) and in various perspectives. Role ambiguity was found to have decreased job performance, satisfaction and commitment (Chang \& Chang, 2007) while studies by Thompson, McNamara and Hoyle (1997), Wolverton, Wolverton and Gmelch (1999) and Koustelios, Theodorakis and Goulimaris (2004), had focused on role ambiguity in relation to education. The tendency for employees in the service setting to experience role ambiguity was investigated by Singh 
(1993). According to Singh, this was mainly due to them having to engage constantly in high interactions with their environment, having to deal with non-programmable decisions and perhaps being expected to hold a variety of role from the internal or the external members of the organization.

The importance for boundary workers to be cleared concerning their job requirements and expectations plays a crucial part in the success in delivering good services. This is because the boundary workers in the service sector have high customers contact. Therefore, in order to determine the importance of employee possessing role clarity and its relationship with their work performance, a study was carried out (Rhoads, Singh \& Goodell, 1994). The study revealed that when workers experienced role ambiguity, they tend to experience poor job performance and this condition had shown that role ambiguity and job performance possessed a negative relationship. The same study also revealed that role ambiguity had a negative influenced on the job satisfaction of employees as well as on their organizational commitment (Rhoads et al., 1994).

Using the seminal work Khan et al. (1964), Smith (2007) found that there was a significant relationship between emotional reactions and job ambiguity. Employees that experienced role ambiguity tends to have uncertainty attached to a scope of responsibilities, about others expectations on them and ways to achieve task success. The study also found that emotional tension increased when ambiguity increased and ambiguity had also reduced job satisfaction. At the same time, the same study revealed that when an employee experiences role ambiguity, they tend to display lower self-confidence, which may have resulted in an ineffective performance in the workplace. Therefore, it can be concluded that when one experiences role ambiguity, one feels more stressful while role ambiguity resulted in lower job satisfaction and self-confidence. Negative correlations were found between role ambiguity and quality of services when the factor was examined in relation to the performance of salespeople. It was found that employees tend to produce the poorer quality of service when they experienced role ambiguity (Wetzels, Ruyter\&Bloemer, 2000). Perhaps the results obtained by Wetzels, Ruyter and Bloemer (2000) occurred simply because when employees are unsure of what was being expected, motivation to exert greater effort in delivering good service tended to be diminishing and ultimately service performance tends to suffer.

Study on role ambiguity and its relationship with gender were conducted by Busch and Bush (1978). The study attempted to determine the differences between females and 
males in the industrial sales force by comparing role clarity, six job satisfaction components, and value importance of the job components, performance, and propensity to leave the organization. Results showed that women tend to experience greater ambiguity pertaining to their role and in turns leading to them having a higher propensity to leave their job as compared to men. This was mainly due to women may be less willing to ask for help and to ask questions as they were afraid of their inquiries being perceived as signs of weakness (Busch \& Bush,1978). The above literature revealed that role ambiguity had often been associated with many factors related to employees. The following section reviewed the literature on the relationship between role ambiguities with the job performance of employees.

\section{G. Role Ambiguity and Job Performance}

Role ambiguity is normally connected with employee job performance. At the point when employees experience part equivocalness, they have a tendency to perform at lower levels (Bhuian, Menguc \& borsboom, 2005). Similarly, the employee has the capacity to perform well if they have clear occupation understanding of what is normal and needed from them (Belmont, Babin \& Boles, 1998). The relationship between ambiguities with job performance had been widely studied in past researchers. Nevertheless, there were often found to have mixed empirical evidence between role ambiguity and performance (Singh, 1993). A meta-analysis based on the work of Mathis and Jackson, (2000) by Tubre and Collins (2000) found that in order for an individual to carry out a task effectively, sufficient information is imperative. This is due to the occurrence of ineffective performance when there is a lack of information regarding what needs to be achieved and the most effective work behavior that can help to achieve that. Although most researchers found a negative relationship between role ambiguity and job performance, the strength of the relationship between role ambiguity and job performance varies greatly depending on the type of work and performance measurement (Mathis, \& Jackson, 2000).

The job performance of front administration workers was contemplated by Singh and Rhoads (1991). It was uncovered there were a few sorts of part equivocalness that administration employees can experience, for example, with their bosses, the organization, moral issues, clients, collaborators, family and different chiefs. Results have shown that these factors can affect employee's job performance negatively. An empirical work of Abramis (1994) further strengthened the studies by Singh and Rhoads (1991) when found evidence that role ambiguity resulted in the reduction in work performance. Role ambiguity was also 
studied at the opposite end of the continuum, which is the role clarity. A study by Murkherjee and Maholtra (2006) with the aim to evaluate the effect of role clarity and its antecedents and consequences on employees of frontline staff in a call center revealed the importance of role clarity in determining the service quality performance with role clarity is strongly related to service quality performance. Therefore, the study conveyed that there be role ambiguity existed among the employees; they were not able to deliver effective job performance. In addition to this Hall (2008) conducted a study on a comprehensive performance measurement system effects on managerial performance with role clarity (goal and process clarity) and psychological empowerment mediating the relationship. In terms of role clarity, a positive relationship was shown to exist between goal clarity and managerial performance but the absence of relations was found between process clarity and managerial performance. On the other hand, dissimilar results were obtained from some previous studies in which role clarity was found not to have a relationship with one's job performance, which means whether one is clear about his or her role or not has no relationship with one's job performance (Michaels, Day \& Joachimsthaler, 1987; Wetzels, Ruyter \& Bloemer, 2000). Anyhow, research by Kahn et.al. (1964), House and Rizzo (1972), as well as by Parasuraman, Zeithaml and Berry, (1988) found otherwise. Their findings revealed that role ambiguity had negatively affected the job performance of employees.

In an attempt to explain the perception that athletes may have to pertain to their role judging from a number of coaches and feedback that they have obtained, Beauchamp, Bray, Eys and Carron (2005) found that when training instruction was being analyzed in relation to role ambiguity, the relationship was found to be significant. The study demonstrated that players' role ambiguity could be reduced if training and instructions from their leader exist. This result implied that training and instruction increase clarity and thus reduces role ambiguity which was in turns resulted in higher performance among the athletes. A culturally diverse study to analyze whether part stressors, for example, part equivocalness and role ambiguity can impact the work conclusion among sales employee in the US, Japan and Korea were done by Dubinsky, Michaels, Kotabe, Chae and Hee-Cheol (1992). The discovering uncovered that role ambiguity had a huge negative association with the employment performance of the workers and there was no distinction in the size of the coefficients when looking at between the three example countries. 


\section{Underpinning Theory and Proposed Research Model}

Even though performance has been a frequent dependent variable in many management studies, the theory of job performance has received little attention (Campbell, 1990; Campbell, 1999). Campbell and Zook (1990) as cited by Delvecchio (1999) explained that Campbell model was first developed and tested for the US Army's "Project A", which looked into the selection and classification research project sponsored by the U.S. Army Research Institute for the Behavioral and Social Sciences. The model by Campbell is considered as the most important model of job performance in the literature which is compared with a few other related theories of performance theories (Hunter, 1983; Pritchard, 1991) and have been adopted by researchers on individual job performance studies (e.g. DelVecchio,1999). Campbell's (1990) model makes clear distinctions between three components, which comprised of performance components, performance determinants, and the antecedents of performance determinants. Since in this study, the purpose is to look at the determinants of performance components, the antecedents of the determinants are not discussed but in general, the antecedents are made up of those variables such as person's abilities, personality, interests, education, and an experience that was lead to individual differences in performance determinants.

Performance segments allude to the productivity measurements that constitute different parts of the general occupation productivity. Campbell's (1990) scientific categorization of performance element incorporates eight general components or measurements: (1) employment particular errand capability, (2) non-work particular undertaking capability, (3) composed and oral correspondence, (4) showing exertion, (5) keeping up individual teach, (6) encouraging associate and group accomplishment, (7) supervision, and (8) administration/Corporation. Campbell placed that each of the eight productivity segments is a capacity of three productivity determinants. Particularly execution part is a capacity of definitive information, procedural, abilities learning, and inspiration (Campbell, 1990; Campbell, 1999). As such, to achieve the practices in one of the measurements, an individual need to comprehend what to do, how to do it and have the craving to do it. In point of interest, decisive information incorporates learning about actualities, standards, objectives, and self- information, which speaks to an understanding of a given undertaking's necessities. Procedural learning and expertise incorporate cognitive aptitudes, psychomotor abilities, physical aptitudes, corporation toward oneself attitudes, and interpersonal aptitudes. Inspiration is a consolidated impact from three decision practices: the 
decision to complete, the level of exertion, and the constancy of the determination (Campbell, 1999).

Figure 1: Proposed Research Model

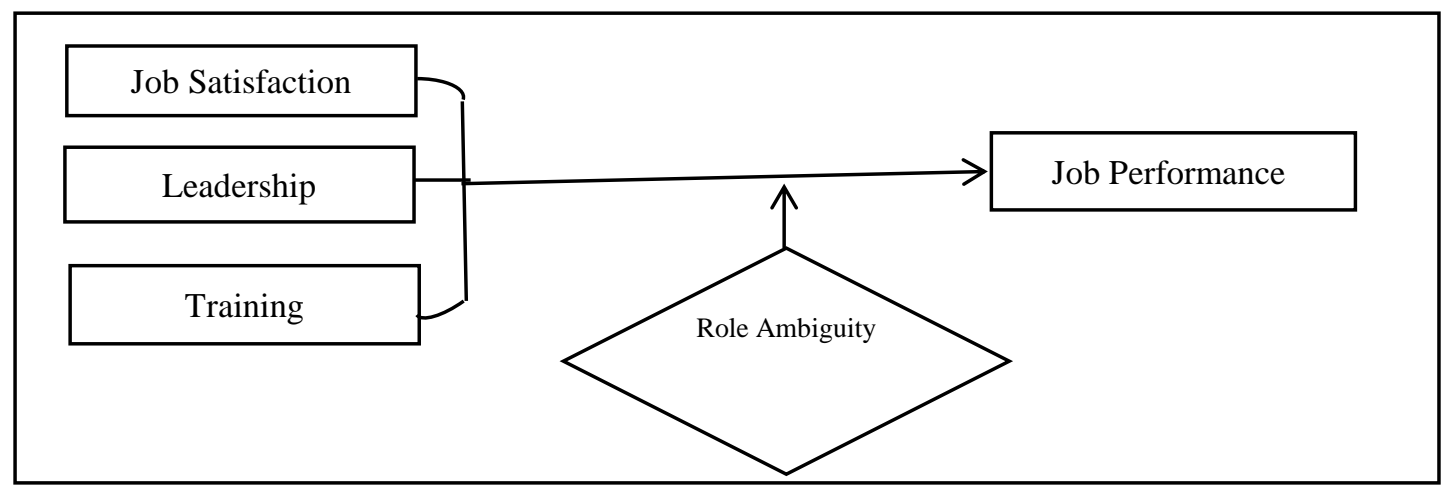

As discussed in the literature and underpinning theories, there are numerous studies that examined the job performance with respect to its various antecedents, most of these studies centered on European countries. The researcher found that previous studies claimed that job satisfaction, has a positive and significant relationship with job performance (Hakeern, 2008). However, job satisfaction of females in the higher education system in Arab countries is not still an ambiguous question. Similarly, the role of leadership in job performance is not clear as leaders with different leadership style tend to influence the performance of their subordinates differently. Most of the studies which describe the relationship between leadership and job performance have ended in both positive and negative conclusions. Moreover, training is a crucial element of high job performance, organizations spend a huge amount in order to train their employees (MacKenzie et al., 2000). It has been identified that leadership and performance have a positive relationship, no linkage, and even negative associations. However, to point out the positive relationship, it can be found in research done by (Mosadegh Rad, \& Yarmohammadian, 2006) as cited in Voon, Lo, and Ngui, (2011). On the other hand, studies concluded that they have found out that these two qualities have a negative correlation with each another. Unfortunately, training not always fruitful for the organizations. As the existing literature on training provides contradictory findings (Sarmiento \& Beale, 2007; Al Ahmadi, 2009). Although there were many variables that have been identified to have an influence on job performance, few of them were consistently supported by studies that investigated specifically on job performance as to how Campbell's (1990) had defined it. This is mainly due to lack of a standard definition of what constitutes job performance (DelVecchio, 1999). Therefore, current study's 
theoretical framework is underpinned by Campbell's performance model and further supported by Herzberg Two- Factor Theory (Herzberg, 1968) as well as Barrett's (1978) Congruency theory. Cambell's job performance model sufficiently explains variables of current study's framework like job performance (dependent variable), leadership (independent variable) and role ambiguity (moderating variable). Thereby, it is adopted as an underpinning theory. Remaining variables like motivation explain by Herzberg's two-factor theory and job satisfaction by Barrett's congruency theory, therefore, adopted as supporting theories. So, the current theoretical model is well aligned and explained by previous theories. Thus, based on the research questions and objectives of this study, a theoretical framework is proposed for future research as shown in Figure 1. This study incorporated the research work by Rizzo et al. (1970), McClelland (1973) and Muchinsky and Monahan (1987) into a multivariate framework that relates the factor of role ambiguity, leadership and job satisfaction with job performance among the employees of the service sector. 
Pakistan Journal of Humanities and Social Sciences, 5(2), 2017

\section{Reference}

Abramis, D. J. (1994). Work role ambiguity, job satisfaction, and job performance: metaanalyses and review. Psychological Reports, 75, 1411-1433.

Ackerman, P.L. (1987). Individual differences in skill learning: An integration of psychometric and information processing perspective. Psychological Bulletin, 102, 327.

Agut, S., \& Grau, R. (2002). Managerial competency needs and training requests: the case of the Spanish tourist industry. Human Resource Development Quarterly, 13 (1), 31-51.

Ahmad, N.H., Ramayah, T., Wilson, C., \& Kummerow.(2010). Is entrepreneurial competency and business success relationship contingent upon business environment? A study of Malaysian SMEs. International Journal of Entrepreneurial Behavior \& Research, 16 (3), 182-203.

Al Gahtani, A. (2002). HRM in Saudi Arabia: a view to the global challenge to our national companies', Paper presented in Arabic at the Fourth HRM Conference, Riyadh, KSA.

Al-Kazemi, A. A., \& Ali, A. J. (2002). Managerial problems in Kuwait. Journal of Management Development, 21(5), 366-375.

Anderson, J.R. (2006). Managing employees in the service sector: A literature review and conceptual development. Journal of Business and Psychology, 20 (4).

Avery, R. D., \& Murphy, K. R. (1998). Performance evaluation in work settings. Annual Review of Psychology, 49, 141-168.

Azmi, I. A. G. (2010). Competency-based human resource practices in Malaysian public sector organizations. African Journal of Business Management, 4 (2), 235-241

Babakus, E., Yavas, U., \& Ashill, N.J., (2009). The role of customer orientation as a moderator of the job demand-burnout-performance relationship: a surface-level trait perspective. Journal of Retailing, 85 (4), 480-492

Babbie, E. (2004). The practice of social research (10th ed.).

Babin, B.J., \& Boles, J.S. (1998). Employee behaviour in a service environment: a model and test of potential differences between men and women. Journal of Marketing, 62, 7791

Beard, F. K. (1999). Client role ambiguity and satisfaction in client-ad agency relationships.Journal of Advertising Research, 39 (2), 69-78. 
Beauchamp, M. B., Bray, S. R., Eys, M. A., \& Carron, A. V. (2005). Leadership behaviours and multidimensional role ambiguity perceptions in team sports.Small Group Research, 36 (1), 5-20.

Beauchamp, M. B., Bray, S. R., Eys, M. A., \& Carron, A. V. (2005). Leadership behaviours and multidimensional role ambiguity perceptions in team sports.Small Group Research, 36 (1), 5-20.

Belmont, CA: Wadsworth Babin, B.J., \& Boles, J.S. (1996). The effects of perceived coworker involvement and supervisor support on service provider role stress, performance and job satisfaction. Journal of Retailing, 72 (1), 57-75.

Bhuian, S.N., Menguc., B. \& Borsboom, R. (2005). Stressors and job outcomes in sales: a triphasic model versus a linear-quadratic-interactive model. Journal of Business Research, 58, 141-50.

Busch, P., \& Bush, R.F (1978). Women contrasted to men in the industrial sales force: job satisfaction, values, role clarity, performance, and propensity to leave. Journal of Marketing Research, 438-448

Campbell, J. P. (1990). Modeling the performance prediction problem in industrial and organisational psychology.In M. D. Dunnette \& L. M. Hough (Eds.), Handbook of industrial and organisational psychology (Vol.1, pp. 687-732). Palo Alto: Consulting Psychologists Press.

Campbell, J. P. (1999). The definition and measurement of performance in the new age. In D. R. Ilgen \& E. D. Pulakos (Eds.), The changing nature of performance: Implications for staffing, motivation, and development (pp. 399-429).

Campbell, J. P., Gasser, M. B., \& Oswald, F. L. (1996).The substantive nature of job performance variability.In K. R. Murphy (Ed.), Individual differences and behaviour in organisations (pp. 258-299).

Chang, T.Y., \& Chang, Y.L. (2007).Relationship between role stress and job performance in salespeople employed by travel agents in Taiwan.International Journal of Stress Management, 14, 211-223.

Chen, S. H., Yang, C. C., Shiau, J. Y., \& Wang, H. H. (2006). The development of an employee satisfaction model for higher education. the TQM Magazine, 18(5), 484500 .

Collis, D. J., \& Montgomery, C. A. (1995). Competing on Resources: Strategy in the 1990s. 
Pakistan Journal of Humanities and Social Sciences, 5(2), 2017

Darandari, E. Z., \& Hoke, T. (2013). Using Quality Assurance Mechanisms to Enhance Change and Organizational Learning. Higher Education Evaluation and Development, 7(3), 37-58.

Delery, E.J., \& Doty, H.D. (1996). Modes of theorizing in strategic human resource management: Tests of universalistic, contingency, and configurational performance predictions. Academy of Management Journal, 39, 802-835.

DelVecchio, W.F. (1999). The dynamic relationship between job satisfaction and job performance. (Doctoral dissertation).Retrieved from ProQuest Dissertations and Theses database. (AAT9938300).

Dubinsky, A. J., Michaels, R. E., Kotabe, M., Lim, C. U., \& Moon, H. C. (1992). Influence of role stress on industrial salespeople's work outcomes in the United States, Japan, and Korea. Journal of International Business Studies, 77-99.

Ericsson, K. A. (2008). Deliberate practice and acquisition of expert performance: a general overview. Academic emergency medicine: official journal of the Society for Academic Emergency Medicine, 15(11), 988-994.

Foot, M., \& Hook, C. (2008). Introducing human resource management. Pearson Education.

Gu, Z., \& Chi Sen Siu, R. (2009). Drivers of job satisfaction as related to work performance in Macao casino hotels: An investigation based on employee survey. International Journal of Contemporary Hospitality Management, 21(5), 561-578.

Hakeern, A. M. B. Almarganhi. (2008). The Relationship between Motivation and Job Satisfaction on Employee's Performance in Universiti Utara Malaysia. Working Paper.

Hall, M. (2008). The effect of comprehensive performance measurement systems on role clarity, psychological empowerment and managerial performance.Accounting, Organisations and Society, 33, 141-163.

Hellriegel, D., Jackson, S. E., Slocum, J., Staude, G., Amos, T., Klopper, H. B., ... \& Oosthuizen, T. (2004). Management: Second South African Edition. Cape Town: Oxford University Press Southern Africa.

Hersey, P., \& Blanchard, K. H. (1993). Management of organizational behavior: Utilizing human resources. Prentice-Hall, Inc.

Holloway, J., Francis, G., \& Hinton, M. (1999). A vehicle for change? A case study of performance improvement in the "new" public sector. International Journal of Public Sector Management, 12(4), 351-365. 
House, R. J., \& Rizzo, J. R. (1972). Role conflict and ambiguity as critical variables in a model of organizational behavior. Organizational behavior and human performance, 7(3), 467-505.

Ilgen, D. R., \& Hollenbeck, J. R. (1991). The structure of work: Job design and roles. Jamjoom, Y. (2012). Understanding Private Higher Education in Saudi ArabiaEmergence, Development and Perceptions. Institute of Education, University of London. Unpublished Ph. D. thesis.

Jamshidi, S., Bagherzadeh, E., \& Nikoo, H. (2011). Studying of relationship between emotional intelligence andemployees performance: case study Bandar Abbas customs in Iran. Shahed University.

Jones, M. K., Jones, R. J., Latreille, P. L., \& Sloane, P. J. (2009). Training, job satisfaction, and workplace performance in Britain: Evidence from WERS 2004. Labour, 23(s1), $139-175$.

June, S., \& Mahmood, R. (2011). The relationship between role ambiguity, competency and person-job fit with the job performance of employees in the service sector SMEs in Malaysia. Business Management Dynamics, 1(2), 79-98.

Kahn, R. L., Wolfe, D. M., Quinn, R. P., Snoek, J. D., \& Rosenthal, R. A. (1964). Organizational stress: Studies in role conflict and ambiguity.

Kahn, R. L., Wolfe, D. M., Quinn, R. P., Snoek, J. D., \& Rosenthal, R. A. (1964). Organizational stress. New York: Wiley.

Koustelios, A., Theodorakis, N., \& Goulimaris, D. (2004). Role ambiguity, role conflict and job satisfaction among physical education teachers in Greece. International Journal of Educational Management, 18(2), 87-92.

Lang, J., Thomas, J.L., Bliese, P.D., \& Adler, A.B. (2007). Job demands and job performance: the mediating effect of psychological and physical strain and the moderating effect of role clarity. Journal of Occupational Health Psychology, 12 (2), 116-124.

MacKenzie, S. B., Podsakoff, P. M., \& Rich, G. A. (2001). Transformational and transactional leadership and salesperson performance. Journal of the academy of Marketing Science, 29(2), 115-134.

Mathis, R. L., \& Jackson, J. H. (2000). Human resource management. Australia: SouthWestern: College Publishing. 
McShane, S. L., \& Von Glinow, M. A. (2010). Organisational behaviour-emerging knowledge and practice for the real world (5th Ed).NY: McGraw-Hill Irwin.

Meglino, B. M., Ravlin, E. C., \& DeNisi, A. S. (2001). A meta-analytic examination of realistic job preview effectiveness: A test of three counterintuitive propositions. Human Resource Management Review, 10(4), 407-434.

Mosadegh Rad, A., \& Hossein Yarmohammadian, M. (2006). A study of relationship between managers' leadership style and employees' job satisfaction. Leadership in Health Services, 19(2), 11-28.

Muchinsky, P. M., \& Monahan, C. J. (1987). What is person-environment congruence? Supplementary versus complementary models of fit. Journal of vocational behavior, 31(3), 268-277.

Mukherjee, A., \& Malhotra, N. (2006). Does role clarity explain employee-perceived service quality? A study of antecedents and consequences in call centres. International Journal of Service Industry Management, 17(5), 444-473.

Mukherjee, A., \& Malhotra, N. (2006). Does role clarity explain employee-perceived service quality? A study of antecedents and consequences in call centres. International Journal of Service Industry Management, 17(5), 444-473.

Parasuraman, A., Zeithaml, V. A., \& Berry, L. L. (1988). Servqual: A multiple-item scale for measuring consumer perc. Journal of retailing, 64(1), 12.

Perie, M., \& Baker, D. P. (1997). Job Satisfaction among America's Teachers: Effects of Workplace Conditions, Background Characteristics, and Teacher Compensation. Statistical Analysis Report.

Potluri, R. M., \&Zeleke, A.A. (2009).Evaluation of customer handling competencies of Ethiopian employees.African Journal of Business Management, 3 (4), 131-135.

Rhoads, G. K., Singh, J., \& Goodell, P. W. (1994). The multiple dimensions of role ambiguity and their impact upon psychological and behavioral outcomes of industrial salespeople. Journal of Personal Selling \& Sales Management, 14(3), 1-24.

Rizzo, J. R., House, R. J., and Lirtzman, S. I. Role Conflict and Ambiguity in Comple Organizations.Administrative Sciences Quarterly. 1970, 15(2): 150-163.

Robbins, Stephen P. and Coulter, M. Management. (2003), Upper Saddle River, New Jersey: Prentice Hall, 2003. 
Royan, S. J., Hamid, A. L., Kovilpillai, F. J., Junid, N. Z., \& Mustafa, W. M. W. (2008). A prospective study on elderly patients with facial fractures in a developing country. Gerodontology, 25(2), 124-128.

Sarmiento, R., Beale, J., \& Knowles, G. (2007). Determinants of performance amongst shopfloor employees: A preliminary investigation. Management Research News, 30(12), 915-927.

Sharma, R. D., \&Jyoti, J. (2010). Job satisfaction of university teachers: An empirical study. Journal of Science Research, 9(2) , 51-80.

Shenkar, O. \&Zeira, Y. (1992). Role conflict and role ambiguity of chief executive officers in international joint ventures. Journal of International Business Studies, 23 (1): 55-75.

Shepherd, C. D., \& Fine, L. M. (1994). Scaling and measurement: Role conflict and role ambiguity reconsidered. Journal of Personal Selling \& Sales Management, 14(2), 5765 .

Singh, A. (1993, December). The plan, the market and evolutionary economic reform in China. United Nations Conference on Trade and Development (UNCTAD).

Singh, J., \& Rhoads, G. K. (1991). Boundary role ambiguity in marketing-oriented positions: A multidimensional, multifaceted operationalization. Journal of Marketing Research, 328-338.

Singh, J., Verbeke, W., \& Rhoads, G. K. (1996). Do organizational practices matter in role stress processes? A study of direct and moderating effects for marketing-oriented boundary spanners. The Journal of Marketing, 69-86.

Smith, F. D. (2007). Job Satisfaction in USA. Chicago: University of Chicago.

Stashevsky, S., \& Koslowsky, M. (2006). Leadership team cohesiveness and team performance. International Journal of Manpower, 27(1), 63-74.

Thompson, D. P., McNamara, J. F., \& Hoyle, J. R. (1997). Job satisfaction in educational organizations: A synthesis of research findings. Educational Administration Quarterly, 33(1), 7-37.

Tomaka, L.A. (2001). Workforce development in the Midwestern region. Spectrum, 74, $26-7$.

Tubre, T. C., \& Collins, J. M. (2000). Jackson and Schuler (1985) revisited: A meta-analysis of the relationships between role ambiguity, role conflict, and job performance. Journal of management, 26(1), 155-169.

Vakola, M., Soderquist, K.E., \&Prastacos, G.P. (2007).Competency management in support of organisational change. International Journal of Manpower, 28 (3/4), 260-275 
Voon, M. L., Lo, M. C., Ngui, K. S., \& Ayob, N. B. (2011). The influence of leadership styles on employees' job satisfaction in public sector organizations in Malaysia. International Journal of Business, Management and Social Sciences, 2(1), 24-32.

Wetzels, M., Ruyter, Ko-de, Bloemer, J., (2000). Antecedents and consequences of role stress of retail sales persons. Journal of Retailing and Consumer Services 7, 65-75.

Winarno, J. 2008. Emotional intelligence sebagai salah satu factor Penunjang Prestasi Kerja. Jurnal Manajemen. 8 (1): 14-17.

Wolverton, M., Wolverton, M. L., \& Gmelch, W. H. (1999). The impact of role conflict and ambiguity on academic deans. The Journal of Higher Education, 70(1), 80-106. 